\title{
CZY ROZUMOWANIE WĘŻA BYLO RZETELNE? KILKA SŁÓW SIĘGAJĄCYCH POCZĄTKÓW NASZEGO MYŚLENIA W DARZE ZNAWCY RACJONALNOŚCI
}

Jak pokazuje sam początek Księgi Rodzaju, dzieje argumentacji są stare jak świat. Ale czy strategia węża (serpent) była wybrykiem jednorazowym, czy powtarza się wielokrotnie w historii myśli ludzkiej i czy jest ona nieodmiennie związana z przekonywaniem nierzetelnym, czy raczej z błądzeniem w rozumowaniach z kwantyfikacją? Niniejszych kilka uwag na ten temat chciałbym dedykować Czcigodnemu Jubilatowi.

Zacznijmy od znanego wszystkim cytatu:

Pan Bóg wziął zatem człowieka i umieścił go w ogrodzie Eden, aby uprawiał go i doglądał. A przy tym Pan Bóg dał człowiekowi taki rozkaz: „Z wszelkiego drzewa tego ogrodu możesz spożywać według upodobania; ale z drzewa poznania dobra i zła nie wolno ci jeść, bo gdy z niego spożyjesz, niechybnie umrzesz" (Rdz 2:15-17).

Zdanie wygłoszone przez Boga do Adama (tu jeszcze „Adam” oznacza rodzaj ludzki) jest dozwoleniem, które można zapisać w następujący sposób:

$\forall x(x \in(E-W) \rightarrow P J(x))$, czyli dla każdego $x$ należącego do zbioru drzew w ogrodzie Eden pomniejszonego o drzewo poznania (zbiór jednoelementowy $W$ zawierający jeden element, który nazwiemy $T$ ) jest dozwolone zjeść owoc z tego drzewa. Trzeba podkreślić, że jest to dozwolenie warunkowe, a nie zakaz. Dozwolenie warunkowe jest czymś powszechnym w prawie (np. jeżeli obywatel ukończył 18 lat i nie jest pozbawiony zdolności do czynności prawnych, ma czynne prawo wyborcze, czyli każdy obywatel oprócz tych pozbawionych zdolności do czynności prawnych ma czynne prawo wyborcze) i nikogo tego typu instytucja prawna nie dziwi. Przekształcając powyższy wzór, można łatwo otrzymać: 


$$
\begin{aligned}
& \forall x((x \in A \wedge \neg x \in B) \rightarrow P J(x)) \\
& \forall x((x \in E \wedge \neg x=T) \rightarrow P J(x)) \text { i w końcu } \\
& \forall x(\neg x=T \rightarrow(x \in E \rightarrow P J(x))), \text { czyli } \forall(\neg P J(x) \rightarrow(x=T \vee \neg x \in E))
\end{aligned}
$$

(Jeśli nie jest dozwolone zjedzenie owocu z drzewa $x$, to jest ono drzewem wiadomości lub nie należy do drzew Edenu).

W następnych wersach Adam stwierdza swoją samotność i wtedy Bóg stwarza „kość z jego kości”, czyli Ewę. Rodzaj ludzki ulega pomnożeniu, dialog staje się możliwy i wtedy na arenę dziejową wkracza wąż (jak się wydaje, może dosłownie wkracza, bo potem za karę ma być pozbawiony zdolności chodzenia, która wszak przysługuje całkiem sporej grupie gadów), który niewinnie zagaduje niewiastę: „On to rzekł do niewiasty: «Czy rzeczywiście Bóg powiedział: Nie jedzcie owoców ze wszystkich drzew tego ogrodu?»" (Rdz 3:1).

Cóż zatem rzekł ów serpent? Można to chyba zapisać w sposób taki:

$\forall x(x \in E \rightarrow \neg P J(x))$, czyli dla każdego drzewa w ogrodzie Eden nie jest dozwolone zjedzenie owocu z tego drzewa. Inaczej mówiąc:

$$
\forall x \neg(x \in E \wedge P J(x)) \text { i stąd } \neg \exists x(x \in E \wedge P J(x))
$$

Oczywiście nie ma sposobu, żeby na gruncie logiki klasycznej przejść od zdania wygłoszonego przez Boga do zdania węża. Czy zatem wąż mógł popełnić tak podstawowy błąd? Wszak „wąż był bardziej przebiegły niż wszystkie zwierzęta lądowe, które Pan Bóg stworzył” (Rdz :1). Odpowiedzią powszechnie znaną jest: nie! On się nie pomylił, ale zwiódł niewiastę. Zasiał w niej niepokój, co widać w sposobie jej obrony: „Owoce z drzew tego ogrodu jeść możemy, tylko o owocach z drzewa, które jest w środku ogrodu, Bóg powiedział: «Nie wolno wam jeść z niego, a nawet go dotykać, abyście nie pomarli»" (Rdz 3: 2-3). Niby powtarza to samo, co Bóg powiedział, ale dodaje ",a nawet go dotykać" - czego Bóg nie powiedział. Jak też nie powiedział, że drzewo jest w środku ogrodu, tylko nazwał je konkretnie drzewem poznania. Oczywiście wąż, dalej kusząc, podkreślił: „Na pewno nie umrzecie! Ale wie Bóg, że gdy spożyjecie owoc z tego drzewa, otworzą się wam oczy i tak jak Bóg będziecie znali dobro i zło" (Rdz 3:4-5). Sugeruje zatem złą wolę Boga, jego chęć zachowania sekretu życia i śmierci dla siebie itd. To temat niezliczonych analiz teologicznych i filozoficznych dotyczących tajemnicy zła i dialogu kuszenia.

Tu wróćmy do owego przejścia: „nie wszystko wolno” - „wszystkiego nie wolno" i szerzej: „wszystkie poza kilkoma, są” (,nie wszystkie są") - „wszystkie nie są”. Skoro wąż był przebiegły, raczej nie był w stanie popełnić elementarnego błędu logicznego; zastosował za to skuteczną (jak pokazały następne wiersze Księgi Rodzaju) strategię argumentacyjną. 
Arystoteles w Dowodach sofistycznych oraz w Retoryce (B24) podejmuje analizę tzw. entymematów pozornych, czyli sylogizmów retorycznych, które są obarczone niepoprawnością logiczną. Oczywiście ta niepoprawność nie jest oczywista, bo wówczas nie miałyby one siły perswazyjnej. Entymematy te (Arystoteles podaje jako przykłady entymematów pozornych dziewięć toposów) można podzielić na trzy grupy:

1) formalnie niepoprawne - traktowane jako sylogizm w jednej $\mathrm{z}$ trzech figur sylogizmu zawierają błąd formalny;

2) materialnie niepoprawne - treść twierdzeń (przesłanek) takiego entymematu jest fałszywa, albo niekonieczna, nieprawdopodobna, lub też wręcz niemożliwa.

3) takie, które łączą w sobie zarówno brak w formie sylogistycznej, jak i w rozumowaniu przez pozornie prawdopodobne przesłanki, a więc imitują wynikanie, które $\mathrm{w}$ rzeczywistości nie zachodzi, na przykład: „[...] jednych ocalił, innych pomścił, wszystkich Hellenów wyzwolił" (Arystoteles 2001, 1401a 10-11); każde z tych zdań jest wnioskiem na podstawie innych przesłanek czy argumentów.

Do grupy pierwszej Arystoteles zalicza m.in. topos dotyczący relacji całość - część.

Inny [topos właściwy dla pozornego entymemu] polega na twierdzeniu o całości na podstawie jej składników i o poszczególnych składnikach na podstawie całości. Całość i jej składniki brane są tu więc za tożsame, chociaż często takimi nie są. Należy zatem dostosować jedną z możliwości, zależnie od tego, która w danym przypadku jest korzystna. [...] Skoro podwójna dawka czegoś jest szkodliwa dla zdrowia, to nie może służyć zdrowiu również pojedyncza, ponieważ byłoby niedorzecznością, że dwie rzeczy dobre tworzą jedna złą (Arystoteles 1998, B1401a) ${ }^{1}$.

Być może zabieg serpenta da się zakwalifikować jako tego rodzaju pozorny sylogizm? Skoro bowiem jakiś element zbioru nie ma własności bycia dozwolonym do zjedzenia, to i cały zbiór nie ma tej własności. Mimo tego, że (prawie wszystkie) elementy zbioru owoców w raju, od strony statystycznej patrząc, są dozwolone do zjedzenia (zakładając, że drzew w Ogrodzie było dużo, prawdopodobieństwo znalezienia owoców dozwolonych było bliskie 1), to jednak manewr węża zadziałał. Skoro element zbioru nie jest dozwolony, to i cały zbiór nie jest (w pełni) dozwolony.

${ }^{1} \mathrm{O}$ entymematach pozornych i szerzej o roli entymematu $\mathrm{w}$ argumentacji $\mathrm{w}$ (Lechniak, Stefańczyk 2018). 
Dlaczego ów schemat działa? Łatwo zauważyć, że jest to pewna wersja błędu pars pro toto; polega on na tym, że (zwykle) koncentrujemy się na własnościach części, nie zauważając, że nie wyczerpują one całego zbioru i że inne przedmioty tego zbioru mogą mieć inne własności (np. rozżalony nauczyciel logiki formalnej konstatuje, że studenci pierwszego roku, których uczy, nie chcą się uczyć logiki, i na tej podstawie stwierdza, że [wszyscy] studenci nie chcą się uczyć logiki). Podstawą takiego rozumowania jest, jak wiadomo, pewien rodzaj indukcji niezupełnej, która jest rozumowaniem nieniezawodnym. Skuteczne użycie pars pro toto jako nierzetelnej strategii argumentacyjnej (entymematu pozornego) musi zatem zasadzać się na tym, że argumentujący dokonuje zabiegu nakierowania uwagi adresata argumentacji wyłącznie na elementy stosownego podzbioru tak, by ten „zapomniał” o (zwykle) przeważającej całości (niemającej danej cechy), a skupił się wyłącznie na podzbiorze przedmiotów daną cechę posiadających (w wypadku błędu naszego nauczyciela logiki są to jego emocje). Formalnie mówiąc, wąż doprowadza do zastąpienia poprzednika implikacji, którą można by uznać za właściwy wyraz zakazu Boga: (oczywiście pierwotnie, jak to mówiliśmy, nie był to zakaz, ale warunkowe dozwolenie) przez warunek, że $x \in E$. W wypadku Ewy tym, co powoduje jej odwrócenie od spełnienia przykazania Boga, jest ukazanie jej przez węża „,atrakcyjności drzewa $T^{\prime \prime}$ w swoistym dialogu kuszenia².

Takie przeniesienie punktu zainteresowania z dozwolonej (w ograniczonym zakresie) całości na zakazaną część ma miejsce, jak się wydaje, wcale nierzadko. Argument zdaje się stosowany np. przez głoszących, że w Polsce wolność słowa nie istnieje, bo nie wszystkie wypowiedzi są dozwolone. Albo: nie ma tolerancji, bo niektóre zachowania są nieakceptowane społecznie. Oczywiście wypowiedzi typu „nie ma (wolności, tolerancji, zrozumienia ${ }^{3}$ )" to skróty od „nie istnieje (wolność, tolerancja,

${ }^{2}$ Przenikliwy opis dialogu kuszenia daje Józef Tischner w eseju Zło w dialogu kuszenia: „Kuszenie jest dialogiem, a więc procesem. Ma ono pewne elementy stałe, a pewne zmienne. Stały jest przede wszystkim ogólny horyzont sprawy: co jest prawdą i kto-z-kim-przeciwko komu? Zmienne są argumenty perswazji, a przede wszystkim obraz kusiciela. [...] Mowa pokusy jest mową pochlebstwa, oskarżenia oskarżycieli, wezwaniem do sprawdzenia, czy zło jest naprawdę złem. Będąc dialogiem, pokusa jest stale zaproszeniem do pogłębienia wzajemności w pochlebstwie, w oskarżaniu oskarżycieli, w sprawdzaniu [...].

Schlebiać znaczy: budzić przekonanie, że człowiek jest godny większego uznania i szacunku, niż uznanie i szacunek, jakie mu ofiarują jego bliscy [w naszym wypadku Bóg - przyp. M.L.]. Pochlebstwo zmierza do przemiany aksjologicznych przeświadczeń kuszonego, związanych z dotychczasowym systemem "uznań. Rozpoczyna: „tamci nie mają racji - mnie nie doceniają". Dodaje: ,jesteś cenniejszy, niż przypuszczasz”. I wreszcie: „naprawdę tylko ja cię doceniam”. I tak już na samym początku pokusy ukazuje się nowa przestrzeń możliwych zawierzeń -nowe: kto-z-kim-przeciwko-komu. Ale zmiana ta dokonuje się jakby ukradkiem, po cichu, w tle rozmowy"; por. (Tischner 1982, s. 340).

${ }^{3}$ Tu często mamy przejście od "on (np. przeciwnik polityczny) nie wszystko rozumie (wiele rozumie, choć są aspekty rzeczy, których nie rozumie)” do „on niczego nie rozumie”. 
zrozumienie)", a przesłanką do takich konkluzji są zwykle stwierdzenia, że w pewnych sytuacjach zakazano komuś wolności wypowiedzi, pewnych zachowań nie dopuszczono czy też pewne osoby czy ich wypowiedzi nie zostały zaakceptowane.

Czasem, choć to nieco inny przykład, możemy mieć też do czynienia z sytuacją że z racji na pewne „wyjątki” gotowi jesteśmy zrezygnować $\mathrm{z}$ „,reguły ogólnej”, powszechnie stosowanej i sprawdzonej siatki pojęciowej itp. Wówczas z racji tego, że dla małej liczby przypadków stosowanie reguły może być dyskusyjne ${ }^{4}$, postuluje się zawieszenie stosowania reguły do wszystkich wypadków. Sytuację tę przypominają np. argumentacje za zastąpieniem dozwolenia stosowania modelu dwupłciowego człowieka przez pojęcie kontinuum płci. Pada wówczas taki argument: ponieważ szacuje się, że 1,7\% (a właściwie od 0,05\% do 1,7\% - przyp. M.L.) populacji nie mieści się w klasyfikacjach opartych na modelu dwupłciowym, należy uznać, że perspektywa feministyczna, wedle której ludzie dzielą się na kobiety i mężczyzn, jest błędna. Innymi słowy, ponieważ nie wszyscy ludzie podlegają modelowi dwupłciowemu, model ten należy odrzucić.

Arystotelesa dyskusja nad entymemami pozornymi pokazuje, że wadliwości te, normalnie niemające prawa wystąpić w racjonalnym dyskursie, w dyskursie retorycznym mogą być częste i niebezpieczne - na ten fakt pragnął zwrócić uwagę Stagiryta, próbując podać w Retoryce jakąś próbę ich klasyfikacji. Oczywiście po zidentyfikowaniu przestają one być niebezpieczne, natomiast zadziwiające jest, że często są skutecznie stosowane. Sukces biblijnego węża jest tego pierwszym, jakże doniosłym przykładem.

\section{Bibliografia}

Arystoteles (1990), O dowodach sofistycznych, [w:] idem, Dzieła wszystkie, t. 1, PWN, Warszawa, s. 476-516.

Arystoteles (2001), Retoryka, [w:] idem, Dzieła wszystkie, t. 6, Wydawnictwo Naukowe PWN, Warszawa, s. 265-477.

Biblia Tysiaclecia (1983), wyd. 4, Pallotinum, Poznań.

Lechniak M., Stefańczyk A. (2018), Strategie argumentacji w teorii retoryki Arystotelesa, „Studia Semiotyczne" 32, 1, s. 61-82.

Mikkola M., Feminist Perspectives on Sex and Gender, Stanford Encyclopedia of Philosophy, https://plato.stanford.edu/entries/feminism-gender/ (dostęp: 18.04.2020).

Peterson P. (1979), On the Logic of "Few", "Many", and "Most”, „Notre Dame Journal of Formal Logic" 20, 1, s. 155-179.

Tischner J. (1982), Zło w dialogu kuszenia, „Znak” 328, s. 340.

${ }^{4}$ Warto by może częściej stosować kwantyfikatory słabsze (lub też zdania kategoryczne słabsze niż te w logice Arystotelesa); logice zwrotów słabszych niż "dla każdego" poświęcony był np. artykuł P. Petersona, On the Logic of "Few", "Many", and "Most" (1979). 
Streszczenie: Czy rozumowanie węża było rzetelne? Kilka słów sięgajacych początków naszego myślenia w darze Znawcy Racjonalności

Artykuł podejmuje zasygnalizowany w Księdze Rodzaju problem przejścia $\mathrm{w}$ argumentacji od stwierdzenia, że wszystko poza jednym jest dozwolone, do konkluzji, że nic nie jest dozwolone. Wyrażono przypuszczenie, że rozumowanie biblijnego węża jest przykładem argumentacji nierzetelnej, pewną wersją argumentu pars pro toto (entymematu pozornego), często pojawiającą się w różnego rodzaju argumentacjach.

Słowa kluczowe: Księga Rodzaju 2-3, wąż, pars pro toto, entymemat pozorny

Summary: Was the Serpent's Argumentation Conclusive? A Few Words That Go back to the Beginning of our Reasoning as a Gift to the Knower of Rationality

The paper deals with the problem of transition in argumentation from a statement that everything except one is permitted to the conclusion that nothing is permitted; the motivation of the analysis is a story of the biblical serpent from Genesis 2-3. We suppose that the reasoning of the serpent is an example of nonconclusive argumentation, i.e.. an argument pars pro toto (apparent enthymeme) which can be often found in contemporary argumentations.

Keywords: Genesis, serpent, pars pro toto, apparent enthymeme 